\title{
Miranda: King Prospero’s Heart and Prosperous Beauty
}

\author{
Mr. Nandeswar Deori \\ Department of English \\ United Tribal Degree College \\ Lakhimpur, Assam \\ gurubor78@gmail.com
}

\begin{abstract}
Miranda is the dear daughter of king Prospero. She is the only daughter of the king. She understands the human values though she had to live with her father in the secluded island. When she was watching the sinking crews of the ship in the tempestuous waves of ocean, her heart begins to wavering if they will die or not. She cannot see the passengers hue and cry. Being a loyal daughter, she begs her father to save the passengers with his supernatural powers. Prospero's deep love for Miranda is perhaps striking, so he says that the passengers will not be harmed but be realized what the grave situation is. The 'rich gift' of Prospero later falls in love with Ferdinand at the first sight whom Ariel isolated from the other members of the crews of the ship and brought to Prospero's cell. Here, Miranda's romantic showers begin to fall upon Ferdinand. She shows herself to be a passionate lover as does Ferdinand too. The intensity of her love begins to increase. The impulses that have been palpitating in her heart deeply and passionately taking about the prince Ferdinand are nothing but 'Eve of an enchanted Paradise'.
\end{abstract}


Keywords: Leniency, Sober, Passionate, Intensity, Immaculate, Innocent, Enchanted.

Miranda is one of the virtuous lady characters that ever created by Shakespeare. Like many other female characters, Shakespeare has created Miranda with a view not only to understand the human values but also how human should extend their hands in the adversity. She shows her human qualities as the normal being though she had to live isolated abstaining from the human bondage in the verisimilitude of her father. She appears for the first time before Prospero's cell in the Act-I, Scene-II, where she pours her forgiveness seeing the ship wrecked men and with a humanist view she says to her father though he can bring about a tempest in the roaring marine waters, he can also control the tempest so that the suffering men are able to save their lives. She shows her leniency towards the disaster-torn men that were suffering by the strike of the foul mounting floods of rain. Her heart has molten that there were noble persons in the ship. Being a loyal daughter, she appeals her father to show mercy towards the pitiful men. Like Perdita, she is pure and innocent in her thinking. She has brought all of the freshness and beauty of the forlorn father as did Perdita bring the smoothness of nature to the stale and stiff court, which later brought new outlooks along with her forgiveness all around. She cannot imbibe the tragic situation of the men who are struggling with the waves of the sea which has dashed vehemently not only the delicate ship but also the unfortunate crews. Therefore, she says to her god-father-

'’Had I been any god of power, I would Have sunk the sea within the earth, or ere It should the good ship so have swallow'd, and The fraughting souls within her." 
She, being a virtuous daughter, tries to prevent her father not to waste the valuable lives because among them some are noble hearts. According to her, made of blood and flesh man should be shown sympathy towards his kinsmen. Her female cheek is as broad as the welkin's cheek which is covered with freshness and sobriety but quietly impress with her lofty thoughts to Prospero as Wordsworth says ''my heart of hearts I feel your might" and feel proud of her radiant thought that sooth the old man's heart and fueling his mind utterly with bless and grace and his grieve disdains thanking her, in the beautiful words of Wordsworth-

" Thanks to the human heart by which we live, Thanks to its tenderness, its joy, and fears.'

She is as lovable and meek as Cordelia. To love of her father is never diminish from her part. She understands her father deeply and shares her weal and woe with her father. She is, like Cordelia, simple and straightforward. She is totally absent from the "glib and oily art" of flattering and moves in chaste actions and honorable steps. Her words are still and soliciting that come out with scintillating remarks. Only childlike uttering words whisper in the ears of Propero even though she has set her foot on puberty. Her nature and temperament fully shows that she is in right perspective and provides the right information to her father. She understands her father properly in dignified way. Her disposition towards her father is loyal and Prospero is her "jewels of our father' as Cordelia remarks. There is no any hypocrisy in her expression. The child is lapping on the full-grown man as the waters lap on the bank. Pity is the very essence in her heart. The frightening sight of the scene of the ship in the vortex pours her tears. She, being a girl, cannot see 
the rousing waves that attack on the human beings and thinks that these ferocious waves will perish the crews immediately forever.

But Prospero, being a well-experienced and well-grown man, is not wavering in her speech. He is well conversant what he has finely been doing with the crews. No any fatal knock will happen. Prospero's action is just only an experimental to the high wrong-doers who don't know real human bond. The learned king tries hard to bring about the re-union of the parted kindred and the atonement for their ferocious wrongs that had fissured among them like huge landmass Gondwana many years ago. The king understands that his relatives once destroyed the pontifical solemnity among their immaculate bond because of their obnoxious and heinous crimes. The aged king also thinks that though the misfortune had pushed him to live a life of loneliness, his pining for love and union is more crucial to his life. The king, despite his cynicism and turbulence, tries to bring about an atmosphere of peace. He thinks that gone are the days of tempestuous and phlegmatic emotionalism but the present is his real asset for him which embrace all kindliness and tolerance exercising the noblest emotions and feelings that touching the human heart. The king comes out from the sullen gloominess with his nobler reasons. He lets his fierce judgment to go and welcomes the humanity and gentility. Therefore, he judiciously says-

"Through with their high wrongs I am struck to the quick.

Yet, with nobler reason, against my fury,

Do I take part: the rarer action is,

In virtue than in vengeance they being penitent,

The sole drift of my purpose doth extend,

Not a frown further.", 
The entire show is happening for the benefits of her because he is maintaining, like a juggler, the ship with his magic but not any harmful result will come out. Prospero says to her, "No harm/I have done nothing but in care of thee." He tells his daughter that he won't harm any one in the ship and can't be seen the slightest injury. He also assures her that even a single hair won't be lost to the crews. Prospero understands thereupon his daughter's conditions which brought her irreparable impression over her mind and therefore he says to her, "The very virtue of compassion (is) in thee',

Like many other female characters of Shakespeare, Miranda shows herself that she is the earthly figure and is made of blood and flesh whose heart is full of tender loves and joys. As Mrs. Jameson logically draws that 'the character of Miranda resolves itself into the very elements of womanhood. She is beautiful, modest, and tender and she is these only; they comprise her whole being, external and internal. She is so perfectly unsophisticated, so delicately refined, that she is all but ethereal'. She does not show the supernatural qualities as does Ariel show himself in the urgent time that demanded by Prospero. Something has blown over her when she for the first time sees Ferdinand. The young girl's spirited mind begins to roll over the handsome and lively prince. She has not long been seen human being living in the isolated island except her father and the 'capable of all ill' Caliban. Having seen Ferdinand among the marooned crews she feels elated and finds him excellent and charming figure like a spirit. Her heart begins to sink to get this spirit. That's why, she asks to her father with tenderness,

'"What is 't? a spirit?

Lord, how it looks about! Believe me, sir, It carries a brave form. But "tis a spirit." 
But Prospero informs her that Ferdinand is not a spirit. He is a human being who feels and thinks like herself. After that Miranda becomes intimate with Ferdinand. At this Prospero understands that his daughter is attracted passionately to Ferdinand as the iron is attracted to magnet. As Mrs. Jameson asserts that "Miranda herself appears a palpable reality, a woman walking the earth in her mortal loveliness, with a heart as frail-strung, as passion-touched, as ever fluttered in a female bosom." She becomes more and more passionate on Ferdinand getting him before her. She begins to seek him like a love-bird. Prospero at this becomes aware that his dear daughter has crossed the border. The king tries so far as to keep distance Miranda from Ferdinand as it might happen the unwanted incident between them. But her love for Ferdinand is so deep like a well that she can assimilate the shrine where good feelings dwell in. So she says to her father-

'There's nothing ill can dwell in such a temple.

If the ill spirit have so fair a house,

Good things will strive to dwell in."

On Miranda's part, Ferdinand is immaculate. According to her, Ferdinand carries a symbol of pure beauty that there is not for a room of abhorrence as does have 'poisonous slave' Caliban. She doesn't like any misbehave of her father on Ferdinand. It brings to her heart a hurtful life since she loves him dearly. Who will keep back the patience, when one's lover is troubled by others whether he is relative or not? She is fully perturbed with her father's harsh behavior. So she replies, "why speaks my father so ungently? The intensity of her love for Ferdinand is as tantamount as Cleopatra to Antonio. But the degree of intensity is different. As Heine says, "love is always a kind of frenzy, more or less beautiful." Miranda's ardour 
and faith on Ferdinand is humanly ideal but Cleopatra's is no less than a maddened meteor.

Prospero ordered Ferdinand to pile some logs of wood near the jungle of his cell. At this Miranda's intensity of love to Ferdinand has been seen. She cannot but help him with her own hand in the massing of woods. His hard labor has brought her a sad. She feels that her lover gets annoyed piling up the logs of wood. Her tender heart spontaneously mulls over Ferdinand that her father has illogically imposed some unwanted burdens. She, being a beloved, suggests Ferdinand therefore to take rest. But Ferdinand has to do his task because he has to keep his honor and prestige before his beloved at any cost. So he tells her,

'O most dear mistress,

The sun will set before I shall discharge

What I must strive to do."

But Miranda's heart does not overwhelm on this, in spite of that she suggests Ferdinand that he should take rest since Prospero is not there but he is involving in the reading of his magic books. In the absence of Prospero, Ferdinand pours his heart into deep love. He says that her beauty and grace is God's grand gift and her jewels. At this Miranda too express that Ferdinand is her only desired lover. She gloats over him that she becomes his wife and maid as the fervent devotee offers to God. She does surrender fully herself to the prince. Therefore, the simple natured girl Miranda exceedingly conveys to Ferdinand,

"I am your wife if you will marry me;

If not, I'll die your maid; to be your fellow

You may deny me; but I'll be your servant,

Whether you will or not." 
Therefore, Mrs. Anna Brownell Jameson capitalizes womanish qualities of Miranda that are tangible to the reality and beautifully demonstrates the princess, 'Miranda herself appears a palpable reality, a woman walking the earth in her mortal loveliness, with a heart as frail-strung, as passion-touched, as fluttered in a female bosom."

\section{References}

Paul, Rajinder: The Tempest. Rama brothers; New Delhi, 2013.

Mukherjee, S. K.: Selected Poems of Wordsworth; Rama Brothers, New Delhi,2008.

Lall, Ramji. King Lear; Rama Brothers, New Delhi, 2008.

www. nosweatshakespeare.com perdita

Jameson, Anna : Shakespeare's Heroines. Books Way, Kolkata, 2013 